\title{
The Effect of Electroporation Method towards the Motility and Viability of Java Barb Fish (Puntius javanicus) Sperm
}

\author{
Dimas Adetia Rikianto ${ }^{1 *}$, Agoes Soeprijanto ${ }^{2}$, Yuni Kilawati ${ }^{2}$ \\ ${ }^{1}$ Master Program of Fisheries and Marine Sciences, Faculty of Fisheries and Marine Sciences, University of Brawijaya, \\ Malang, Indonesia \\ ${ }^{2}$ Faculty of Fisheries and Marine Sciences, University of Brawijaya, Malang, Indonesia
}

\begin{abstract}
Electric shock treatment of Java Barb Fish (Puntius javanicus) sperm using electroporation method on sperm as transfer gen (Sperm Mediated Gen Transfer) has not been implemented in Indonesia. This study was conducted to know the effect of electric shock using gene pulser at different voltage level toward motility and viability of Java barb fish sperm. This research was conducted at Fish Breeding Labroratory, Faculty of Marine and Fisheries and LSIH of Brawijaya University-Malang in May 2017. The trial design used Complete Randomized Design with 3 different treatments and 1 control which each treatment repeated 3 times. The treatments used the Gene pulser with 3 different voltages: A (20 V), B $(30 \mathrm{~V}), \mathrm{C}(40 \mathrm{~V})$. The result showed that the electric shock treatment with different voltages level affected motility and viability of Java barb fish sperm. Based on the data analysis used polynomial orthogonal, a linear-form of the relationship among the treatments in the form of equation was found (Puntius javanicus) with $R^{2}=0.9815$ and equation $y=-$ $40.5 x+130.83$ with $R^{2}=0.8626$. Based on the result of this research, electroporation for Java barb fish' sperm as gene transfer media should be done with voltage $20 \mathrm{~V}$, pulse number 4 times and pulse length $1 \mathrm{~ms}$.
\end{abstract}

Keywords: electroporation, motility, Puntius javanicus, sperm, viability.

\section{INTRODUCTION}

Sperm is spermatozoa fluid found in the seminal fluid produced from the testicle hydration or a part of fish' reproductory organ [1]. The amount of sperm produced by male fish has various volume and quality which are influenced by the age, size and the ejaculation frequency [2].

Java Barb fish belongs to the commodity of freshwater fish as the member of the silver carp family. The spermatozoa of silver carp fish have length around $\pm 24 \mu \mathrm{m}$. It has round head with the length of $\pm 1.5-2 \mu \mathrm{m}$ and width of $\pm 1.5-1.8 \mu \mathrm{m}$ [3].

The motility and viability of sperms are important parameters that determine the success of fertilization process. Sperm motility shows the ability of the spermatozoa in fertilizing the ovum. The higher the motility value, the higher the survival percentage (viability) of the spermatozoa [4].

Gene transfer technology in Java Barb Fish (Puntius javanicus) using sperm as a gene transfer media has not been implemented in Indonesia. Microinjection was commonly used as

\footnotetext{
* Correspondence author:

Dimas Adetia Rikianto

Email : dimasadetia30@gmail.com

Address : Faculty of Fisheries and Marine Sciences, University of Brawijaya, Jl. Veteran Malang, 65145
}

gene transfer method. One of the weekneses of this method is take a long time process. The eggs must be injected one by one and not practical to mass produce fish, further needs another alternative that is electroporation method. The advantages of electroporation methods can produce mass transgenic fish and electroporation methods can be combined with Sperm Mediated Gen Transfer (SMGT), where sperm was used as a transfer media. Further research is needed on the effect of electric shock treatment of fish sperm through electroporation method. Previous study added the advantages of the electroporation method that can insert most of the DNA copies into the recipient fish genome. Electroporation method can be combined with Sperm Mediated Gen Transfer (SMGT), where sperm as its transfer media [5].

Electroporation method is a gene transfer method using a set of short electric shocks to stimulate temporary pores to grow within the phospholipid bilaer. After being given electric shock, the pores of the cell membrane will be tightened again [6]. Factors that influence the transfection efficiency using the electroporation method are the voltage, duration, temperature, DNA adjustment, DNA concentration and ion composition within the transcription mediators [7]. Electric shock given to muscle tissue has two effects which are; changing the structure of 
muscle tissue permeability, besides electroporation also helps transferring the DNA throughout the membrane permeability [8]. The objective of this study was to see the effect of the electric shock given, using the gene pulser at different voltages toward the motility and the viability of Java Barb Fish' sperm.

\section{MATERIALS AND METHODS}

The experiment design used in this research was the complete random design. There were 3 treatments and 1 control in which each was repeated 3 times. The treatments employed in this study were:

Treatment $A=$ electric shock at $20 \mathrm{~V}$

Treatment $\mathrm{B}=$ electric shock at $30 \mathrm{~V}$

Treatment $\mathrm{C}=$ electric shock at $40 \mathrm{~V}$

Control = without any electric shock

Determination treatment with different voltages level $(20 \mathrm{~V}, 30 \mathrm{~V}, 40 \mathrm{~V})$ in this study based on the result of previous research on Japanese carp (Cyprinus carpio var.Koi) sperm using electroporation method with voltage level $30 \mathrm{~V}$ [9]. In each of the treatment, the electric shock was given for $1 \mathrm{~ms}$ repeated 4 times, except for the control [9].

\section{Preparing the Sperm Striping}

Preparation on the male fish with mature gonad was to produce the sperm. The male fish with mature gonads were then measured its length and weight. The sperm was taken using the stripping method which was later kept in the eppendorf. The sperm was then diluted by adding it up with physiologic fluid at the comparison $1: 1$. Then, the researchers prepared the electroporation tools [10].

\section{Electroporation Process}

Total $25 \mu$ l of sperm was put into the cuvette, before the cuvette was put into the shock pod. After that, the voltage of square wave was chosen and adjustment on the strength of the electricity, shock duration and the shock frequency were made before the pulse button was pushed to start the shock. This treatment was repeated 3 times for each of the voltage [9].

After being shocked with the electricity, the liquid sperm was added with Physiologic Natrium in the cuvette. After theat, the sperm was poured into the appendorf and each of the $25 \mu \mathrm{l}$ of sperm was observed to see its motility and its viability [9].

\section{Research Parameters \\ Motility of the Spermatozoa}

Spermatozoa motility is a beneficial parameter that is used to predict the life time of the spermatozoa. Alive sperms are the ones that show fast movement, slow movement or show any movement on their heads or tails. Meanwhile, dead sperms are those that do not show any movement either in the head or in the tail [11].

The percentage of motile sperm is measured using a microscope which is completed with video recorder. Motile sperm is counted when the sperm show progressive movements. Sperm that shows no movement or sperm that goes around only in certain point are considered dead ones. The scoring (Table 1) was made based on the method proposed by McMaster [12]. To assure the validity of the data and to assure the objectiveness, the score was only given after observing the video with some repetitions [12].

Table 1. Criteria of Sperm Motility Categorization

\begin{tabular}{ll}
\hline Criteria & Score \\
\hline Very poor (only 0-20\% Progressive motile) & 1 \\
Poor (only 20-40\% Progressive motile) & 2 \\
Good (only 40-60\% Progressive motile) & 3 \\
Very good (60-80\% Progressive motile) & 4 \\
Excellent (80-1000\% Progressive motile) & 5 \\
\hline
\end{tabular}

Source: McMaster [12]

\section{Viability of the Sperm}

The viability of the sperm was observed using a technique that employed the eosin hue and negrosin. A small drop of sperm and a drop of eosin negrosin fluid were put in an object glass to be mixed until it looked homogeneous. After that, in a petri dish, the sperm was heated in order to drain it which process lasted for 15 seconds. The sperm was then observed using a microscope at 400x magnification [13].

Sperm viability $=\left(\sum\right.$ live sperm $\left.\times 100 \%\right) / 200$

\section{Data Analysis}

The data obtained in this study were statistically analyzed using the homogeneity test (ANO$\mathrm{VA}$ ) in accordance to the complete random design used in this study. Based on the variance of the data, it is found that there was an obvious significant difference up to highly significant difference after the treatment. Thus, in order to compare the values of each treatment, a Least Significant Difference and regression test were administered. 


\section{RESULT AND DISCUSSION Spermatozoa Motility}

The result of the motility test administered to the spermatozoa of the Java Barb fish in each of the treatment after the electroporation and after the repetition is presented in Table 2 . Based on the data of the average motility value, it is shown that the highest motility percentage was found in the control group (without the electroporation) at an average of 5\%. Meanwhile, the highest motility percenteage among the experiment groups was found in the treatment $A(20 \mathrm{~V})$ at the percentage of $3.67 \%$, while the lowest one was found in the treatment C (40V) at $0.17 \%$. When the motility of the control group compared to the motility of the treatment group, a decline in the values occurred as presented in Figure 1.

Table 2. Spermatozoa Motility (\%)

\begin{tabular}{|c|c|c|c|c|c|}
\hline \multirow{2}{*}{$\begin{array}{c}\text { Treatment } \\
\text { (\%) }\end{array}$} & \multicolumn{3}{|c|}{ Repetition } & \multirow[b]{2}{*}{ Total } & \multirow[b]{2}{*}{ Average } \\
\hline & 1 & 2 & 3 & & \\
\hline A & 4 & 3 & 4 & 11 & 3.67 \\
\hline B & 2 & 2 & 3 & 7 & 2,33 \\
\hline C & 0.5 & 0 & 0 & 0.5 & 0.17 \\
\hline Total & & & & 18.5 & \\
\hline Control & 5 & 5 & 5 & 15 & 5 \\
\hline
\end{tabular}

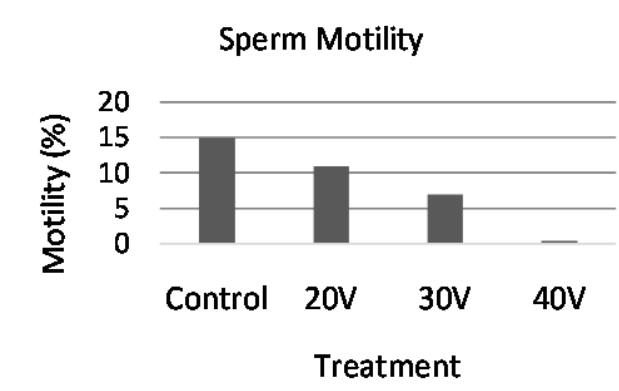

Figure 1. Sperm Motility Diagram

Figure 1 shows that the electroporation treatment using electric shock influence the motility of the fish' sperm. The higher the amount of the electric shock given, then lower the motility of the fish. The voltage and the shock frequency and the biological parameters of the sperm are able to influence the effectiveness, while the shock duration influences the efficiency of the gen transfer using certain DNA concentrate. The motility of the sperm tends to decline as the voltage increases and longer shock duration [14]. Previous study highlighted that the electric shock given to the muscle tissue plays two roles; changing the permeability structrure of the muscle tissue, while the electroporation helps the DNA transfer to pass through the membrane permea- bility. Membrane permeability of the spermatozoa is highly reated with the spermatozoa motility since the membrane permeability has a major role in the nutrition transportation in the cell metabolism process. The sperm cells tend to shirnk after the electroporation which explains the declining percentage of the sperm motility [8].

Based on the result of variance test presented in Table 3 significant differences were found. This shows that different voltage gives different influence toward the percentage of the sperm motility which implies that the $\mathrm{H}_{1}$ is accepted and the $\mathrm{H}_{0}$ is rejected. After that, Least Significant Difference test was administered which result is presented in Table 5.

Table 3. Result of Variance Test on the Sperm Motility

\begin{tabular}{|c|c|c|c|c|c|c|}
\hline \multicolumn{7}{|c|}{ Percentage } \\
\hline Source & df & SS & MS & $\mathbf{F}$ & F 5\% & F $1 \%$ \\
\hline Treatment & 2 & 18.72 & 9.36 & $37.44 *$ & 5.14 & 10.92 \\
\hline Random & 6 & 1.50 & 025 & & & \\
\hline Total & 8 & & & & & \\
\hline \multicolumn{7}{|c|}{ Notes: ${ }^{*}=\mathrm{F} 5 \%<$ F value $>$ F $1 \%$} \\
\hline \multirow{2}{*}{ Treatment } & \multirow{2}{*}{\multicolumn{2}{|c|}{ Average }} & C & B & A & \multirow{2}{*}{ Notation } \\
\hline & & & 0.17 & 2.33 & 3.67 & \\
\hline C & & .17 & - & & & a \\
\hline B & & .33 & 2.16 & - & & $\mathrm{b}$ \\
\hline A & & 67 & 3.50 & 1.34 & - & $b$ \\
\hline
\end{tabular}

Notes: Similar notes shows no difference

The result of the Least Significant DIfference test shws that the treatment $A(20 \mathrm{~V})$ has the best motility followed by the treatment $B(30 \mathrm{~V})$ and treatment $C(40 \mathrm{~V})$. The highest motility value was obtained by the treatment $A$ for the sperm cells were in the most optimal condition compared to the sperm cells in treatment $B$ and $C$ which were treated with higher voltage, making the the motility value declined.

This is different from the results of Japanese Carp (Cyprinus carpio var.Koi) Luthfiyah et al. [15] which obtained the best results on $10 \mathrm{~V}$ treatment with motility score 4 and the lowest at $40 \mathrm{~V}$ with motility a score of 0.5 [15]. The treatment in this study without using level voltage (10V) because of based on the result from previous research in carp fish (Cyprinus carpio) by electroporation method on sperm with the best result treatment was voltage level (30V) [9]. Further, the motility and viability of Java barb fish sperm using treatment with voltages level among 
the previous treatment ( $20 \mathrm{~V} 30 \mathrm{~V} 40 \mathrm{~V})$. Sperm motility after the electroporation process relies on the voltage, shock length, shock frequency, and the buffer ionic power [16].

Furthermore, the polynominal orthogonal test resulted to a linear equation $y=-1.75 x+5.5556$ with a correlation coefficient of 0.9815 which implies that different voltages and motility has a strong correlation with the treatment given as presented in Figure 2.

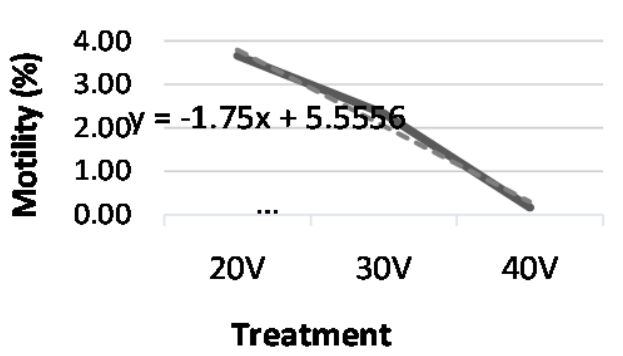

Figure 2. Relationship between Different Voltages and the Sperm Motility

Figure 3 shows that the treatment resulted to a decline on the sperm motility duration as the voltage got higher compared to the sperm in the control treatment.It implies that the the cell sperm which is given short electric shock stimulates the growth of temporary pores in the bilayer phospholipid of the cel membrane that allows the penetration of new DNA into the cell. After the electric shock, the cell membrane will get tightened again [6].

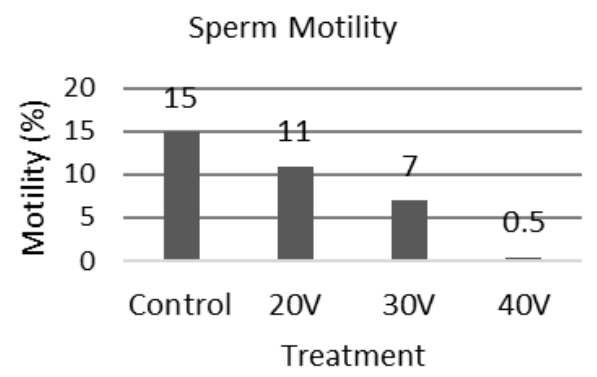

Figure 3. Motility Duration of the Sperm in the Control Group and after being given with Treatment

Based on this theory, food fluid exhance with outside the cells may occur for the metabolism of the sperm which results to the declining motality duration. This is due to the fact that the sperm need energy to make movement. Fructose fluid as the dissolver to the fish' spermatozoa are intended to supply energy and nutrition for the spermatozoa to use the energy in the form of ATP to increase and prolong the spermatozoa motility duration [17].
The condition of the fish' sperm determines the success of the fertilization. Strong sperms are able to fertilize the egg successfully. Changes that occur to the sperm will influence the quality of the sperm. The changes include the motility and the viability of the sperm. Good seminal fluid for the fertilization process should consist of lots of live sperms that move forward progressively. The percentage of the motile sperm should be more than $75 \%$. For daily use, the sperm motility should not be less than $50 \%$ even some researchers suggest that it should be more than $60 \%[18]$.

\section{Spermatozoa Viability}

The result of the viability measurement of the Java Barb fish' sperm after the electroporation using different voltages can be seen in Table 5 . Based on the observation, it is found that the highest viability percentage was found in the control group (without electric shock) at $85.66 \%$. Meanwhile, the highest percentage among the treatment group was achieved by the treatment A (20 V) at $81.00 \%$ and the lowest one was fond in the treatment $\mathrm{C}(40 \mathrm{~V})$ at $00.00 \%$.

Table 5. Spermatozoa Viability

\begin{tabular}{|c|c|c|c|c|c|}
\hline \multirow{2}{*}{ Treatment } & \multicolumn{3}{|c|}{ Repetition } & \multirow{2}{*}{ Total } & \multirow{2}{*}{$\%$} \\
\hline & 1 & 2 & 3 & & \\
\hline A & 81 & 83.5 & 78.5 & 243 & 81.00 \\
\hline B & 43 & 88.50 & 74 & 205.5 & 68.50 \\
\hline C & 0 & 0 & 0 & 0 & 0.00 \\
\hline Total & & & & 462.5 & \\
\hline Control & 77 & 86 & 94 & 257 & 85.66 \\
\hline
\end{tabular}

Figure 3 shoes that the percentage of the sperm viability declined in each treatment. Furthermore, the result of the variance test (Table 6) shos that different voltages give different influences toeward the fish' sperm viability. Therefore, the $\mathrm{H}_{1}$ is accepted.

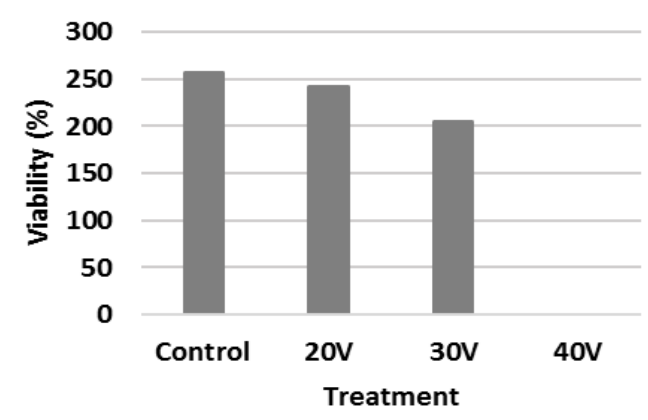

Figure 3. Sperm Viability in the Control Group after being given Electric Shock 
(Rikianto et al.)

Table 6. The Result of Variance Test on Sperm Viability

\begin{tabular}{ccccccc}
\hline $\begin{array}{c}\text { Variance } \\
\text { source }\end{array}$ & df & SS & MS & F & F 5\% & F 1\% \\
\hline Treatment & 2 & 11409.5 & 5704.75 & 31.31 & 5.14 & 10.92 \\
Random & 6 & 1093.00 & 182,16 & & & \\
Total & 8 & & & & & \\
\hline
\end{tabular}

The result of the Least Significant Difference test shows that the treatment $A(20 \mathrm{~V})$ contributes the highest sperm viability value followed by the treatment $B(30 \mathrm{~V})$ and $C(40 \mathrm{~V})$. The highest viability value was found in the treatment $A$ since the sperm cells were still in the best condition compared to the sperm in treatment $A$ and treatment $C$ for higher voltages decreases the motility value. This finding goes in line with $\operatorname{Sin}$ et al. (2000) who stated that the sperm motility is the indicator of the sperm viability after the electroporation, in which higher voltages and longer shock duration decrase the sperm motility [14].

Table 7. Least Significant Difference Test

\begin{tabular}{cccccc}
\hline \multirow{2}{*}{ Treatment } & \multirow{2}{*}{$\%$} & $\mathbf{C}$ & $\mathbf{B}$ & $\mathbf{A}$ & \\
\cline { 3 - 5 } & & 0.00 & 68.50 & 81.00 & \\
\hline $20 \mathrm{~V}$ & 0.00 & - & & & $\mathrm{a}$ \\
\hline $30 \mathrm{~V}$ & 68.50 & 68.50 & - & - & $\mathrm{b}$ \\
\hline $40 \mathrm{~V}$ & 81.00 & 81.00 & 12.50 & - & $\mathrm{b}$ \\
\hline
\end{tabular}

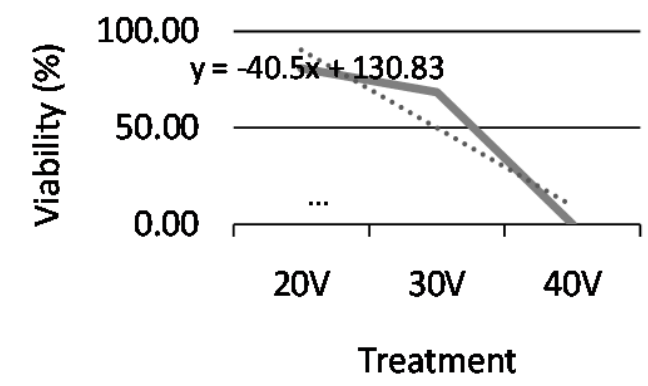

Figure 4. Relationship between Different Voltages and Sperm Viability

The result of the Least Significant Difference test shows that the treatment $A(20 \mathrm{~V})$ achieved the highest sperm viability value followed by the treatment $B(30 \mathrm{~V})$ and treatment $C(40 \mathrm{~V})$. In addition, based on the result of the polynomial orthogonal test, an equation has been obtained in which $y=-40.5 x+130.83$ with correlational coefficient $(r)$ at 0.8626 which implies that different voltages and sperm viability share with the treatment given to the sperm as illustrated in Figure 4. This is in accordance with the results of the study Luthfiyah et al. [15], based on the observation of motility and viability on post electroporation sperm, it is known that the increase of voltage (electric voltage) given at the time of sperm electroporation affects the decrease in the intensity of movement and ability of sperm to survive. It can be seen from the observation result $E\left(40 \mathrm{~V} \cdot \mathrm{cm}^{-1}\right)$, where the value of motility score was only 0.5 and viability was $25.4 \%$. That is because electroporation of sperm gives a very real effect on the biological and physiological conditions of sperm cells. This happens because an excessive electric shock can cause the sperm cell to lose its elastic properties. Therefore, in the activity of gene transfer using electroporation method, optimization is necessary to know the ability of sperm in becoming gene transfer vector [15].

The decrease on the sperm viability is mostly caused by the electric shock given to the sperm causes the pores to open way too wide, making the pores unable to get tightened like before. This causes the cells to break and triggers damages to the sperm membrane [19]. The membrane permeability of spermatozoa has a strong relationship with the spermatozoa biablity sicne membrane permeability has a major role in the nutrition transportation within the cell metabolism process [11].

It has been known that the percentage of the sperm viability determines the quality of the sperm. It means that higher amount of live sperm determines the success of the fertilization. The minimum percentage of spermatozoa cell within the sperm should not be less than $70 \%$. The higher the amount of the sperm viability, the better the ability of the spermatozoa to pass through the micropile holes within the ovum [20].

\section{CONCLUSION}

The experiment on the use of electric shock using the electroporation method toward the Java Barb fish' sperm shows that the electric shock has a significant influence toward the motility and the viability of the sperm. To obtain the best effectiveness level of the motility and the viability of the sperm using the electroporation method, it is suggested that breeders use 20 Volt electric shock with 4 times of repetition in which each of the shock lasts for $1 \mathrm{~ms}$. Further research is needed for sperm motility and viability of Java barb fish with electroporation method using 10 Voltage levels. 


\section{REFERENCES}

[1] Harvey, B.J., B.J. Hoar. 1979. The teory and practice of induce breeding in fish IDRC-TS 21e. International Development Research Centre. Ottawa, Canada.

[2] Rustidja. 2002. Diktat Kuliah breeding dan reproduksi hewan air. Faculty of Fisheries and Marine Sciences. University of Brawijaya. 4-16.

[3] Verma, D. K., P. Routray, C. Dash, S. Dasgupta, J.K. Jena. 2009. Physical and biochemical characteristics of semen and ultrastructure of spermatozoa in six carp spesies. Turk. J. Fish. Aquat. Scie. 9. 67-76.

[4] Junior, M.Z., S. Handayani, I. Supriatna. 2005. Kualitas sperma Ikan Batak (Tor soro) hasil kriopreservasi semen menggunakan Dimetilsulfoksida (DMSO) dan Gliserol 5, 10 dan 15\%. Jurnal Akuakultur Indonesia. 4(2). 145-151.

[5] Kang, J.H., G. Yoshizaki, O. Homma, C.A. Strunsmann, F. Takashima. 1999. Effect of an osmotic differentiation on the efficiency of gene transfer by electroporation of fish spermatozoa. Aquaculture. 173. 297-307.

[6] Nakamura, H. 2009. Electroporation and sonoporation in developmental biology. Springer.

[7] Chen, G., M. Hongbao. 2005. Gene transfer technique. Nat. Sci. 3(1). 25-31.

[8] Andre, F.M, J. Gehl, G. Sersa, V. Preat, P. Hojman, J. Eriksen, M. Gotzio, M. Cemazar, N. Pavsel, M.P. Rols, D. Miklavcic, E. Neumann, J. Teissie, L.M. Mir. 2008. Efficiency of high- and low-voltage pulse combinations for gene electrotransfer in muscle, liver, tumor and skin. Hum. Gene Ther. 19. 1261-1271.

[9] Anitasari, S., A. Soeprijanto, A.R. Faqih. 2015. The effectiveness of hrGFP Gene Reporter role in Carp Fish (Cyprinus carpio) transgenesis process based on convocal microscopy analysis. J. Exp. Life Sci. 5(2). 8288.

[10] Syahputra, K., A. Didik, P.H. Erma, Lamanto. 2014. Efektivitas transfer dan analisis ekspresi gen imunogenik tahan Koi Herpes Virus (KHV) pada Ikan Mas (Cyprinus carpio). J. Ris. Akuakultur. 9(1). 15-23.

[11] Faqih, A. R. 2011. Penurunan motilitas dan daya fertilitas sperma Ikan Lele Dumbo (Clarias $\mathrm{spp}$ ) pasca perlakuan stress kejutan listrik. J. Exp. Life Sci. 1(2). 72-82.

[12] McMaster, M.E., C.B. Portt, K.R. Munkittrick, D.G. Dixon. 1992. Milt characteristics, reproductive performance, and larval survival and development of white sucke rexposed to bleached kraft mill effluent. Ecotox. Environ. Saf. 23. 103117.

[13] Susilowati, S. Hardijanto, T.W. Suprayogi, T. Sardjito, T. Hernawati. 2010. Penuntun praktikum inseminasi buatan. Airlangga University Press. Surabaya.

[14] Sin, F.Y.T., S.P. Walker, J.E. Symonds, U.K. Mukherjee, J.G.I. Khoo, I.L. Sin. 2000. Electroporation of salmon sperm for gene transfer: efficiency, reliability, and fate of transgene. Mol. Reprod. Dev. 56(52). 285-288.

[15] Luthfiyah, S., S. Agoes, K. Yuni. 2017. The quality of Ornamental Japanese Carp (Cyprinus carpio var. Koi) after electroporation as a gene material transfer method. J. Exp. Life Sci. 6(2). 95-100.

[16] Symonds, J.E., S.P. Walker, F.Y.T. Sin. 1994. Development of mass gene transfer method in Chinook Salmon: optimization of gene transfer by electroporated sperm. Mol. Mar.Biol. Biotech. 3. 104-111.

[17] Hidayaturrahmah. 2007. Waktu motilitas dan viabilitas spermatozoa Ikan Mas (Cyprinus carpio L.) pada beberapa konsentrasi larutan fruktosa. Jurnal Bioscientiae. 4(1). 918.

[18] Hafez, E.S.E. 1987. Semen evaluation. In: Hafez, E.S.E. (Ed). Reproduction in farm animals. Lea and Febiger. Philadelphia. 287297.

[19] Weaver, J.C. 1995. Electroporation theory: concepts and mechanisms. In: Nickoloff, J.A. (Ed). Electroporation protocols for microorganisms. Humana Press. Totowa.

[20] Chen, T.T., M.J. Chen, T.T. Chiou, J.K. Lu. 2009. Transfer of foreign DNA into aquatic animals by electroporation. In: Nakamura, $H$. (Ed). Electroporation and Sonoporation in developmental biology. Springer. 229-237. 